\title{
The Effect Of The Health Belief Model Approach On The Prevention Of Human Immunodeficiency Virus/Acquired Immunodeficiency Syndrome In Pregnant Women
}

\author{
Wida Rahma Arwiyantasari*, Budi Laksana \\ Muhammadiyah Midwifery Academy of Madiun, Indonesia \\ *widarahma541@gmail.com
}

\begin{abstract}
HIV is a virus that attacks the white blood cells (lymphocytes) in the body which causes a decrease in the human immune system, causing Acquired Immunodeficiency Syndrome (AIDS). East Java Province is in the top five in which the population is infected with HIV and it is dominated by men. This will worsen the condition of women if infected with pregnant women, so that the pregnant women are also affected by HIV/AIDS infection. The objective of this study was to analyze the effect of the Health Belief Model approach on the prevention of HIV/AIDS in pregnant women in Madiun City. This type of research was an observational analytic study. The sampling technique used total sampling. The sample size was 80 pregnant women in Madiun City who carried out HIV/AIDS testing. The data collection tool used a questionnaire. The data analysis used Chi-Square and Multiple Logistic Regression analysis. There was a statistically significant effect. Perceived severity, perceived barriers, perceived vulnerability, and perceived benefits affect pregnant women in preventing HIV/AIDS.
\end{abstract}

Keywords : Health Belief Model, Pregnant Women, HIV/AIDS testing 


\section{STRADA Jurnal Ilmiah Kesehatan}

DOI: $10.30994 /$ sjik.v9i2.403

ISSN: 2252-3847 (print); 2614-350X (online)

Vol.9 No.2 November 2020 Page.976-980

\section{BACKGROUND}

Human Immunodeficiency Virus (HIV) is a disease that has the highest risk of the death rate. HIV is a virus that attacks white blood cells that causes AIDS (Acquired Immunodeficiency Syndrome). UNAIDS data in 2014 worldwide showed that 35 million people lived with HIV and 19 million people did not know their HIV positive status. In the Asian region, most of the HIV prevalence rates in the general population are still low, which is $<1 \%$, except in Thailand and North India (Ministry of Health of RI, 2011). The HIV/AIDS epidemic is a problem in Indonesia because Indonesia is the $5^{\text {th }}$ most at-risk country in Asia (UNAIDS, 2013). East Java Province is in the top five in which the population is infected with HIV $(8,204)$ and AIDS $(741)$ and it is dominated by men (Ministry of Health of RI, 2013). This will worsen the condition of women if infected with pregnant women, so that the pregnant women are also affected by HIV/AIDS infection. HIV/AIDS testing services are regulated in Regulation of the Minister of Health of the Republic of Indonesia number 21 of 2013. At the time of antenatal examination, HIV testing is the critical gateway (Ministry of Health of RI, 2013). Examination of HIV/AIDS testing for pregnant women is one of the health behaviors in the prevention and early detection of HIV/AIDS. Antenatal Care (ANC) is a routine health examination service for pregnant women to diagnose obstetric complications and to provide information about lifestyle, pregnancy, and childbirth (Ministry of Health of RI, 2016). Factors that cause pregnant women do not carry out HIV testing early include the possibility of lack of information, ability, and support from their families and some women do not realize that their sexual partners are at risk of HIV-AIDS transmission. Besides these factors, there are influential maternal behavioral factors, which are individual readiness to change behavior according to the Health Belief Model (HBM) theory developed by M. Rosentock (Priyoto, 2014) to avoid a disease or minimize health risks, and encouragement in the individual environment to change behavior, and the behavior through the Health Belief Model.

\section{METHODS}

The research method used in this study was an observational analytic study, with a crosssectional design approach. The research location was in 3 main community health centers in Madiun City which have VCT service facilities. The sampling was carried out by using the total sampling technique. The subjects or samples of this study were pregnant women in the $1^{\text {st }}, 2^{\text {nd }}$, and $3^{\text {rd }}$ trimesters who lived in Madiun City who came to carry out HIV/AIDS testing in April and May 2020, and 80 women were selected as the research subject. The multivariate analysis used multiple logistic regression test.

\section{RESULTS}

The calculation results of multivariate analysis used multiple logistic regression to determine the effect of the Health Belief Model (perceived severity, perceived barriers, perceived vulnerability, and perceived benefits) on HIV/AIDS testing can be seen from Table 1.1.

Table 1.1. Multiple logistic regression analysis

\begin{tabular}{lcccc}
\hline \multicolumn{1}{c}{ Variable } & OR & \multicolumn{2}{c}{ CI 95\% } & p of Wald \\
\cline { 3 - 4 } & & Lower limit & Upper limit & Test \\
\hline Perceived Severity & 8.43 & 1.38 & 51.4 & 0.021 \\
Perceived Barriers & 0.13 & 0.02 & 0.86 & 0.034 \\
Perceived & 8.36 & 1.06 & 65.9 & 0.044 \\
Vulnerability & & & &
\end{tabular}




\section{STRADA Jurnal Ilmiah Kesehatan}

DOI: $10.30994 /$ sjik.v9i2.403

ISSN: 2252-3847 (print); 2614-350X (online)

Vol.9 No.2 November 2020 Page.976-980

\begin{tabular}{lcccc} 
Perceived Benefits & 12.6 & 1.37 & 115.5 & 0.025 \\
N observations & 80 & & & \\
-2 log likelihood & 35.05 & & & \\
Nagelkerke $\mathrm{R}^{2}$ & $81.5 \%$ & & & \\
\hline
\end{tabular}

The Odds Ratio value for the perceived severity variable was 8.43 , which means that pregnant women with high perceived severity were 8.43 times more likely to carry out HIV/AIDS testing than pregnant women with low perceived severity. The Wald test results showed that there was an effect of perceived severity on HIV/AIDS testing and it was statistically significant $(\mathrm{OR}=8.43 ; \mathrm{CI}=95 \% ; 1.38$ to $51.4 ; \mathrm{p}=0.021)$.

The Odds Ratio value for the perceived barriers variable was 0.13 , which means that pregnant women with high perceived barriers were 0.13 times more likely to carry out HIV/AIDS testing than pregnant women with low perceived barriers. The Wald test results showed that there was an effect of perceived barriers on HIV/AIDS testing and it was statistically significant $(\mathrm{OR}=0.13 ; \mathrm{CI}=95 \% ; 0.02$ to $0.86 ; \mathrm{p}=0.034)$.

The Odds Ratio value for the perceived vulnerability variable was 8.36 , which means that pregnant women with high perceived vulnerability were 8.36 times more likely to carry out HIV/AIDS testing than pregnant women with low perceived vulnerability. The Wald test results showed that there was an effect of perceived vulnerability on HIV/AIDS testing and it was statistically significant $(\mathrm{OR}=8.36 ; \mathrm{CI}=95 \% ; 1.06$ to $65.9 ; \mathrm{p}=0.044)$.

The Odds Ratio value for the perceived benefits variable was 12.6, which means that pregnant women with high perceived benefits were 12.6 times more likely to carry out HIV/AIDS testing than pregnant women with low perceived benefits. The Wald test results showed that there was an effect of perceived benefits on HIV/AIDS testing and it was statistically significant $(\mathrm{OR}=12.6 ; \mathrm{CI}=95 \% ; 1.37$ to $115.5 ; \mathrm{p}=0.025)$.

The Nagelkerke $\mathrm{R}^{2}$ value was $81 \%$, which means that the four independent variables (perceived severity, perceived barriers, perceived vulnerability, and perceived benefits) were able to explain the HIV/AIDS testing by $81.5 \%$, and the remaining $18.5 \%$ was explained by other factors outside the research model.

\section{DISCUSSION}

The results showed that there was an effect of the perceived severity of the disease by carrying out HIV/AIDS testing and it was statistically significant. The more serious or more severe disease was, the person would make efforts to take prevention, which was by testing for HIV/AIDS. This study supports a study that stated that low perceived severity affected the use of IVA screening (Nurfazriah, 2015). Pregnancy is a physiological condition, but the importance of pregnancy diagnosis cannot be ignored (Cuningham et al., 2010). The results of the study showed that there was a relationship between perceived barriers and HIV/AIDS testing and it was statistically significant. This means that the higher the perception of a barrier in carrying out behavior, the smaller the success of that behavior. This study supports a study that stated that there was a relationship between barriers and behavior in the use of VCT at the Community Health Center of Dupak and there was a relationship between barriers and prevention behavior of STI and HIV among FSW in Klaten Regency (Budiman, 2008).

The results of the study showed that there was an effect between the perceived vulnerability of an individual and HIV/AIDS testing behavior and it was statistically very significant. When an individual realizes that they are vulnerable or susceptible to a disease, in this case, HIV/AIDS, they will make an effort to prevent the disease by carrying out an 


\section{STRADA Jurnal Ilmiah Kesehatan}

DOI: $10.30994 /$ sjik.v9i2.403

ISSN: 2252-3847 (print); 2614-350X (online)

Vol.9 No.2 November 2020 Page.976-980

HIV/AIDS testing. This is in accordance with the HBM theory developed by Rosenstock that the perception that an individual is susceptible to contracting a disease will make them take protection.

There are several risk factors that increase the possibility that transmission will occur. The most influencing factors are the level of the mother's viral load (the amount of virus in the blood) and preterm birth (the baby is born too early), and lack of HIV care before delivery. Some of the key points include: a baby's HIV status is affected by the health of the mother; the HIV status of the baby was not affected at all by the HIV status of the father; the HIV status of the baby is not affected by the HIV status of other children of the mother (Spiritia 2010). Determining HIV status early during pregnancy is very beneficial for women and babies. The results of the study on the bivariate analysis showed that there was an effect between perceived benefits and HIV/AIDS testing behavior and it was statistically very significant. This means that the higher the perception of the benefits of an action to prevent disease, there was no effect on taking the action. Browning et al. (2015) stated that the vulnerability perceived by pregnant women in carrying out HIV/AIDS testing was an effort to make themselves recovered (sick role behavior).

The results of the study showed that the Nagelkerke $\mathrm{R}^{2}$ value was $81 \%$, which means that the four independent variables (perceived severity, perceived barriers, perceived vulnerability, and perceived benefits) were able to explain the HIV/AIDS testing by $81.5 \%$ and the remaining $18.5 \%$ was explained by other factors outside the research model. The authors concluded that perceptions or assumptions about the severity of a disease, in this case, HIV/AIDS, make pregnant women willing to carry out HIV/AIDS testing. This is because they do not want to get serious diseases so they will make efforts to prevent the disease. A study also showed that there was a relationship between transgender sexual behavior and HIV/AIDS transmission in Tarakan City, East Kalimantan Province, with pvalue $=0.037$ (Faulina, 2009). The HBM theory developed by Rosenstock stated that the higher level of confidence in strategies designed to reduce the threat of disease will automatically take these precautionary measures, in this case carrying out the HIV/AIDS testing. Determining HIV status early during pregnancy is very beneficial for women and babies (Ghozali, 2009). The high rate of transmission is related to high levels of the virus in maternal plasma (Setiawan, 2010).

Therefore, HIV testing should be offered to pregnant women and pregnant women who have been at risk. Maternal HIV/AIDS risk factors can be transmitted to the baby (Bock, 2018). However, testing should be carried out voluntarily, without coercion, and complemented by pre-test and post-test counseling, and with informed consent. Based on the explanation above, the authors concluded that by determining the benefits of testing for HIV/AIDS, pregnant women will be more interested and more aware of the importance of these tests and will not think twice about carrying out HIV/AIDS testing.

\section{CONCLUSIONS}

Based on the explanation above, it can be concluded that there is a statistically significant effect of the perceived severity, perceived barriers, perceived vulnerability, and perceived benefits on HIV/AIDS prevention in pregnant women.

\section{REFERENCE}

Bock. (2018). Factors Influencing The Uptake of Voluntary Counceling And Testing In Namibia. Netherlands; University Amsterdam. 


\section{STRADA Jurnal Ilmiah Kesehatan}

DOI: $10.30994 /$ sjik.v9i2.403

ISSN: 2252-3847 (print); 2614-350X (online)

Vol.9 No.2 November 2020 Page.976-980

Browning, C. J., \& Thomas, S.A. (2015). Behavioural Change An Evidence-Based HandBook For Social and Public Health. Sidney

Budiman, N. A., Istiarti, T., \& Hadi, S. (2010). Faktor Yang Berhubungan dengan Praktek WPS Jalanan dalam Upaya Pencegahan IMS dan HIV-AIDS di Sekitar Alun-Alun dan Candi Prambanan Kabupaten Klaten. Promkes Indonesia Vol 3. 108.

Cuningham CK, Chaix M-L, Rekacewicz C, Britto P, Rouzioux C, Gelber RD, et al. (2010). Developmnet of Resistant Mutations in Woman Receiving Standart Antiretroviral Therapy Who Received Intrapartum Nevirapineti Prevent Perinatal Human Immunodeficiency Virus Type-1 Transmission: A Substudy of Pediatric AIDS Clinical Trials Group Protocol 316. J Infect Dis 2002;186:181-8.

Faulina, R. (2009). Perilaku Seks Waria Kaitannya dengan Penularan HIV-AIDS di Kota Tarakan Provinsi Kalimantan Timur. Semarang : Tesis, Universitas Diponegoro

Ghozali, I.(2010). Aplikasi Multivariate Dengan Program SPSS. Semarang : Universitas Diponegoro

Kementerian Kesehatan RI. (2011). Laporan Perkembangan HIV/AIDS Triwulan IV Tahun 2011. Jakarta : Kementerian Kesehatan RI.

Kementerian Kesehatan RI. (2013). Pedoman Nasional Tes dan Konsuling HIV dan AIDS. Jakarta: Kementerian Kesehatan RI

Kementerian Kesehatan RI. (2016). Buku Kesehatan Ibu dan Anak. Jakarta : Kementerian Kesehatan RI.

Kementerian Kesehatan RI. (2018). Situasi Umum HIV/AIDS dan Tes HIV. Jakarta : Kementerian Kesehatan RI

Nurfazriah O, Maulida. (2015). Hubungan antara Persepsi Kerentanan Individu, Persepsi Keseriusan Penyakit, Manfaat dan Hambatan dengan Penggunan Skrining Inspeksi Visual Asam Asetat Pada Wanita Usia Subur. Surakarta : Universitas Sebelas Maret.

Priyoto. (2014) Teori Sikap \& Perilaku dalam Kesehatan. Nuha Medika: Yogyakarta.

Setiawan, Saryono. 2010. Metodologi Penelitian Kebidanan D3, D4, S1 dan $S 2$.Yogyakarta : Nuha Medika

Spiritia (2010). Dasar AIDS. http://spiritia.or.id/art/pdf/a1001.pdf. Diakses tanggal 8 April 2020.

UNAIDS. (2013). UNAIDS Report 2013: HIV in Asia and the Pasific.

UNAIDS. (2014). The Gab Report

World Health Oganization. (2013). UNAIDS and UNODC. Policy Brief: Reduction of HIV

Transmission In Prions. Geneva:WHO.

Wang, Ya-Hui and Cing-Fen Tsai. (2014). The Relationship Between Brand Image and Purchase Intention: Evidence From Award Winning Mutual Funds. The International Journal of Business and Finance Research, Vol. 8 No. 2. 